\title{
RADICAL THACIPR
}

A SOCIALIST, FEMINIST, AND ANTI-RACIST JOURNAL ON THE THEORY AND PRACTICE OF TEACHING

\section{"It's Alright, Ma (I'm Only Bleeding)": Literature and Language in the Academy}

by Louis Kampf

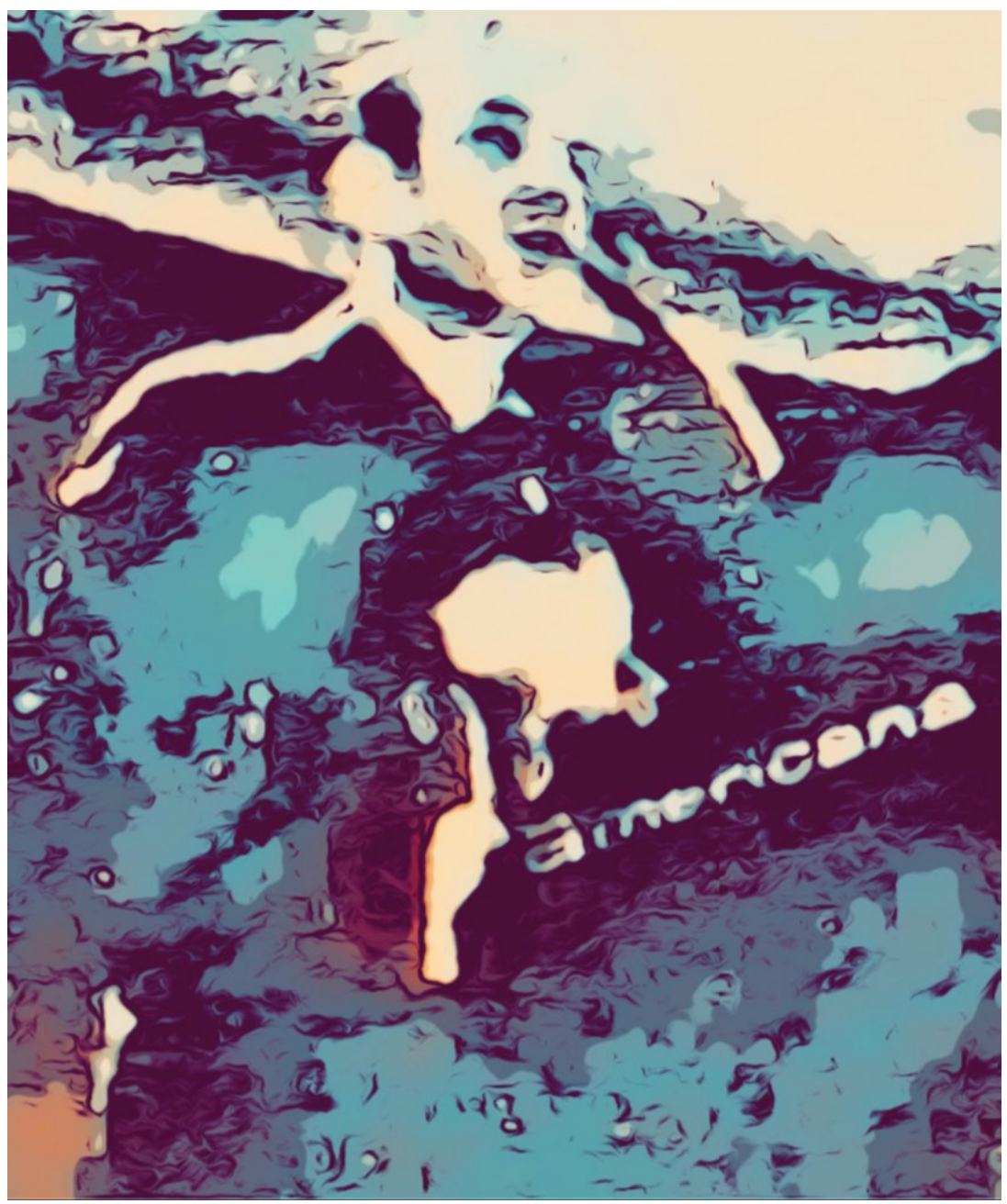




\section{Preface to Louis Kampf's 1971 MLA Address}

\section{by Paul Lauter}

It's 1968, a lovely year: Martin Luther King, Jr. and Bobby Kennedy are murdered. Rebellions all over America follow King's assassination and help bring the war home. In Vietnam itself, the National Liberation Front and North Vietnamese carry out an offensive over Tet, the Vietnamese New Year, that is terrible in its costs but that reduces to rubble American claims to "progress" in the war. Nevertheless, napalm, agent orange, and antipersonnel bombs continue to rain down from American planes onto Vietnamese rice fields and dikes. Back home, Dr. Benjamin Spock, America's favorite baby doctor, the Rev. William Sloane Coffin of Yale, and three other men are indicted for aiding and abetting draft resistance, which is growing apace. Catholic radicals break into a draft board in Catonsville, MD, take out draft files, and burn them with home-made napalm. Soon after, the mayor of Chicago, Richard Daley, encourages his rarin'-to-go cops to break the heads (and arms and legs) of protesters outside the Democratic National Convention, where Hubert Humphrey is being nominated for president. Humphrey will lose the election to Richard Nixon, later to become the first American president forced to resign. And in late December of that very year, the Modern Language Association (MLA), an organization for professors of literature and languages, arrives in New York for its annual convention at the Hilton and Americana hotels.

Just before the MLA meeting, a group of us radicals, including Dick Ohmann, Florence Howe, Paul Lauter, Elaine Reuben, and, of course, Louis Kampf, hold an open meeting at Columbia to talk about "stirring things up" at the staid MLA. What might we do to respond to the brutal events of 1968? Someone designed a button--"Mother Language Association"--others put together posters like one saying "The Tygers of Wrath are Wiser than the Horses of Instruction." Others still began developing a call to set up a Commission on the Status of Women in the Profession. At the convention, we organized ourselves into a Tactics Committee that met frequently in Ohmann's room at the City Squire and morphed into an on-going Radical Caucus in English and the Modern Languages. We passed out buttons, circulated petitions, and put posters on the hotel walls. In fact, Louis and two others were arrested and put in jail for trying to keep the hotel dicks from tearing down our posters. That led to pickets, protests, and ultimately at the annual business meeting a motion to nominate our jailbird comrade Kampf to the position of MLA second vicepresident. He represented the kind of change many of those gathered at the meeting in New York were demanding of their professional association, as well as of their country. From that elected status he would, in the normal course of things, succeed to the presidency in two years. He did. And thus the speech that follows.

\section{"It's Alright, Ma (I'm Only Bleeding)": Literature and Language in the Academy}

\section{Reprint of the 1971 MLA Address by Louis Kampf}

Things appear to be quiet on the campus. Quiet enough, at the moment, for people to believe that if they only close their eyes long enough, the 1960's will be erased from the book of history. The building occupations, the ghetto uprisings, the protests against the war and repression, women's liberation, the challenges to the curriculum and university governance, all are as the shadows of the burning Vietnamese huts we saw on our TV screens who knows how many years ago. Shut your eyes a bit tighter and even the shadows will disappear. We shall once again pursue our affairs in the soft light of Humanism; the return to normalcy will be complete.

Unfortunately, the desperate look of some job seeker slinking past us in a hallway might remind us of just what that normalcy is. Our departments of language and literature, our institutions, have become enclaves of the comfortable, around which scurry the hopeful, looking for the opening that will allow them to creep inside the walls. Nothing strange here. Aren't our departments, after all, merely images of the larger society? Our cities, as Jules Feiffer reminds us in Little Murders, present the spectacle of the well-to-do living in strategically fortified neighborhoods and apartments, fighting off the forays of those who would like to attain the comforts of those inside. Or think of fortress North America, bulging from overproduction, protecting itself from the covetous with all the scientific armor billions of dollars will buy. In the light of the shrinking job market and the over-production of Ph.D.'s, our universities and colleges have become such enclaves. I would like to ask whether education actually goes on in these bastions of normalcy. Or is our departments' main task the selection of winners in the competition for the shrinking number of places inside the enclaves? What better way than that competition to keep the clamor outside the gates?

But the clamor is there. Besides, for many who have gotten one foot inside the gate--never mind the unemployed--the whole business has turned sour. The nasty competition for advancement in the profession is not quite what they expected. The condition of the job market has reminded them that they are indeed part of the market economy, bad investments in human capital development, an unfortunate statistic in the latest report from the Department of Labor. And only a few, they know, will manage to get that second foot inside, into the imagined security of the enclave. Reflecting on such affairs, those petitioning for entry might indeed wonder what their goal has to do with education.

Looking at the demoralized state of our profession, those of us who feel secure in the return to normalcy might also wonder. Consider the condition of North American prose. In the peaceful atmosphere of our classrooms we teach writing, and hold before our students the masterworks of Western prose as models. Yet our teaching seems to have produced no George Jackson's, no Malcolm X's, no Eldridge Cleaver's--all of whom learned their craft in prison. Yet prisons have hardly been quiet enclaves of humanistic 
learning. For George Jackson the struggle to learn language was the struggle to attain a sense of his historical situation as a black prisoner, a sense of his worth as a social and political being. Such quests for the social sources of one's own humanity rarely take place in enclaves devoted to separating the business of intellect from the clamor of the world outside. There may be more than one kind of prison.

This truism many have discovered as the value of our enterprise has begun to slide away. Some of those fortunate enough to have penetrated the enclave have begun to think of it as a prison. But why? We can deal with this question by asking ourselves why the profession attracted us in the first place. A cynic might say that there was nothing else to do. This may be the beginning of an answer, but I doubt that mere lack of direction provides an incentive strong enough to explain why so many persist in jumping those hurdles placed in the way of the Ph.D. Every graduate student I have known has looked at the degree program as an inane ordeal; yet until recently, few doubted that the goal of becoming a critic-teacher-scholar made the bitter pill at least palatable. My own experience, I suspect, was not untypical. The impulses which led me to the study of language and literature are far from clear. Yet I am certain that I drifted toward the profession of literature and to the academy with the hope of doing work which would not be alienating. It was wholeness I yearned for: unity of ideological purpose and economic necessity, of leisure and the way I earned my daily bread. It seemed obvious that teaching and writing about literature would not only be enjoyable, but, more nobly, part of the process of creating an adversary culture. Against a world devoid of beauty, torn apart by irrationality, tragically flawed by human limitations, stood the life of the literary critic-teacher-scholar--a life devoted to civilized reflection, to bringing light where there had been ignorance. In short, I felt confident that performing my task as a literary man would improve my own life, that of my students, and humanity in general.

\section{It seemed obvious that teaching and writing about literature would not only be enjoyable, but, more nobly, part of the process of creating an adversary culture.}

Such faith has served to justify nearly all teaching and research in the humanities. At some level anyone who comes into our profession believes in the redemptive power of literature, its capacity to ennoble a fallen world. There may be truth in such assertions. There may not. Unfortunately, hardly anyone ever attempts to specify how literature performs its magic act. How, in fact, will its study make for a better world? The politics of this trans- formation are invariably left out. Indeed, faith in literature's dogma of redemption depends on one's willingness--perhaps desire-to skirt the realm of society, politics, and institutions altogether. For in the work of its major exponents-Coleridge, Arnold, I. A. Richards--the dogma reduces itself to an assertion of literature's therapeutic power for the individual. In a disordered world, poetry, we have been taught, has the power to impose order on experience, to resolve contradictions; literature's attribute of imagination, by transcending the realm of social experience, transforms divisive struggle into concord. But literature performs these functions in the private world of our feelings. Its capacity to bring wholeness to our lives depends on its construction of an emotive and intellectual world which exists apart from the everyday, utilitarian one. Matthew Arnold gives the notion its most eloquent expression. The critical enterprise, he tells us, is the search for "a perfection which consists in becoming something rather than in having something, in an inward condition of the mind and spirit, not in an out- ward set of circumstances." Those outside the enclave might, of course, like to have something, like a job or tenure, before they turn inward to cultivate perfection. But concern for such externalities comes suspiciously close to betraying the very justification of our critical and pedagogical pursuits.

Arnold's humanistic rhetoric has served the profession well. I say rhetoric advisedly. For there is no substantive argument illustrating how the powers of literature (and criticism) lead people to perfection without the mediation of institutions. Yet we tend readily to accept--indeed, wildly applaud--any eloquent variation on Culture and Anarchy. The notion of an inward realm of perfection is, of course, deeply embedded in our culture. In the arts it has been given nearly official status by philosophy's creation of an autonomous esthetic faculty. "Everyone," Kant wrote, "must concede that judgment about beauty in which the slightest interest interferes is highly partisan and not a pure judgment of taste." We academics have broadened Kant's notion to include all aspects of our institutional lives. Disinterested judgments, we like to claim, are our professional concern; making them distinguishes us from those caught in the rush of everyday affairs; moreover, their dissemination amongst our peers makes the world, somehow, a more rational, a better place. And so the practical expression of the ideological support we have built for the study of literature has been to substitute thought for action. The very nature of the esthetic faculty seems to legislate such practice.

How consoling. The perversities and contradictions of everyday life dissolve in bottomless seas of thought. A naive spectator from the nonacademic world might wonder just who such practice is available to. Lord Kames, in discussing esthetic judgments, gives us a useful hint: "Those who depend for food on bodily labor," he wrote, "are totally void of taste, of such taste at least as can be of use in the fine arts. This consideration bars the better part of mankind." Kant's disinterested judgments of taste are available only to those who spend most of their time in mental activity--that is, the intelligentsia. Most literary academics might attach a few qualifiers to Lord Kames's remarks--but, I suspect, a very few. After all, our departments are the very enclaves which shield us against the intrusions of partisan demands, those constant assaults on our capacities to make pure judgments of taste. Thinking for a living is what separates us from those clamoring outside the gates who earn their keep by doing physical labor. It is the source of our social superiority; it locates us in a more elevated class within the structure of society; it defines our superiority by our capacity to be disinterested.

But just how disinterested are our judgments? Separating thought from work and action, theory from 
practice, and designating thought and theory as superior, intrinsically more noble activities, clearly serves the social interests of those who do intellectual work. There is a lesson to be learned in the political function of ideology by considering that notions like Kant's and Lord Kames's became nearly unquestioned truths for the upper classes at a historical moment--the Enlightenment--when the intelligentsia began tentatively to assume its function within a developing industrial capitalism. To define intellectual activity as superior, as that toward which all activity should strive, and to characterize its highest functions by disinterest--this surely is to formulate a self-serving ideology for people like ourselves. It should hardly come as a surprise that the intelligentsia will generalize its own interests into the interests of humanity: what's good for us is good for everybody, and therefore above class interest or social conflict. Thus the enclave inside which we live pretty well and even enjoy ourselves is really for the benefit of humanity--except most of it has to be kept out.

But then there seems to be the sour taste. The satisfaction just isn't that great. Somehow many of us don't feel so noble. The very arguments we use to support our professional activities turn against us, if looked at from a different perspective. When we insist that literary (or any other) study inside the enclave is separate from political action, we seem to confirm that our professional activities are unrelated to anyone but ourselves and our colleagues. The knowledge produced by scholarship is then related only to other knowledge of a similar sort. Such thoughts undercut the humanistic justification for what we do. Alas, the enterprise begins to sound like a fraud. The assaults during the 1960's on academic pieties made many of our trainees suspect that knowledge is power only for those who have the power to put it to use. Often enough, the suspicions have refused to disappear. And thus the nagging feeling that if humanists are serious about their wares, they must struggle for the power to have them put on the market. Or we can hang on to our self-justifying ideology and relegate literature to an autonomous esthetic realm. But this, one should be clear, is to condemn it to triviality. Or to a game. Which may be fine. But why expect any dean or regent--not to speak of those outside the gates--to help us make a comfortable living for playing a game. Not in this society.

And so to reality. We teach language and literature, whatever our intentions, not in some abstract realm, not in and for themselves, but within institutions. These institutions--grammar schools, colleges, high schools, community colleges, and on to the highest academies-serve a major function within the political economy. Education, I hardly need point out, is a gigantic industry, and still growing. I do not have the time to elaborate on the industry's means of production, distribution, and consumption, or on the social role it plays. However, the literature on the subject is substantial; and those who wish to inform themselves can readily do so. Here briefly are a few of education's more obvious functions: it generates economic growth and is the major factor in what economists call human capital development; it serves to channel and "differentiate" the labor force, thereby creating the necessary pools of people with the requisite skills; it keeps the young off a labor market which contracts as industrial technology advances; it serves as the main instrument of social stratification, while trying to convince people that they've had an equal chance to make it to the top. All these functions are generated by the dynamics of industrial capitalism. But what of higher education's most important product--knowledge? As Kenneth Galbraith has admirably illustrated, the industrial state and its member industries are dependent on knowledge and on the skills, habits of mind, and values of a technostructure or intelligentsia. The economy needs research and development so it can expand; expansion demands rationalization of the process of production and consumption; and all depend on personnel with conceptual skills, valuing intellect, showing just enough competitive fervor, competent at solving problems, and submissive to a rationalized routine. Higher education is not the only agency capable of providing these services; nor does it necessarily do so in the most efficient manner possible; but then it does what it does at the taxpayer's expense, rather than industry's--which may be one reason for higher education's phenomenal growth. English does its bit by teaching the skills of writing, organizing reports, critical detachment, and by introducing students to the dominant values of the culture. As for foreign languages, their study serves many of the same functions as that of English. But let me quote from an American Council of Learned Societies report on the need for more foreign language study published in PMLA (68, Sept. 1953, 56).

The product of American industry spreads all over the world. Wherever there is a paved road there is an American automobile; American oil is produced wherever there is oil and used wherever oil is used. American banks have branches and connections in every significant foreign city. No region is too remote to be the concern of American diplomacy. And all too frequently American armed forces must ply their trade in lands and among peoples whose very names would have been unknown to an earlier generation.

Resonant sentiments for the last year of the Korean war. The report concludes that "the importance of language study in meeting this situation is clear."

The institutions for which we work exist because they are part of a rationalized arrangement for the profitable use of knowledge. As for our specific jobs, they exist because the knowledge produced and imparted by these institutions has itself been rationalized. The nature of our work, of what we teach and write, was, after all, not fixed at the creation, nor was it determined by a group of educational administrators sitting around a table, but by large historical developments. In the United States, the academic study of English, modern languages, and literature goes back little more than a century; the first Ph.D. in English is no more venerable. Indeed, the division and subdivision of knowledge is one cultural product of industrial capitalism's need for rationalization. And from this need derive professional fields, departments, subfields, periods, courses, degrees. Departments of language and literature exist not because of our students' human needs, not because they represent transcendental categories, not to give play to our curiosity, our need to know, but because they help to rationalize the process of educational consumption and production. As does the MLA. We are members of a modern professional organization with a corporate structure, a large 
bureaucracy, appropriately elegant quarters, underpaid secretaries and clerks, a computer, sections, groups, insurance plans, charter flights, competing cliques and individuals trying to hold on to and enlarge their piece of turf. Any professional organization's primary task is to help rationalize its field by putting the official seal on the going standards, creating both formal and informal networks of power, integrating the field into the larger society, and making the distribution of manpower more convenient for employers. The MLA has served the industrial state well enough, though not as well as it might have. How much efficiency can one expect from literary folks, after all.

The nature of our Association points to the contradictions between our humanistic ideology and our practice as professionals. Who are we? And what do we do? We think of ourselves as teachers, as bearers of culture to the young; but what we teach are subjects structured by the rationalization of knowledge. We think of ourselves as scholar-critics making our contribution to the body of useful knowledge, and refining the taste of the general reader; but we write articles and books to get promoted or to sustain our self-respect. A few other scholar-critics might read our productions; some might even review them; still, their destiny is to become items in a bibliography consulted by graduate students suffering through their theses. What does this have to do with criticism as the instrument of perfection?

Which brings me back to why many of us went into the profession in the first place: the promise of unalienating work. That promise has faded for most of us: the young go into the profession with dread; the old can hardly wait for retirement; and those of middle age yearn for sabbaticals. The sourness begins to turn to acid as many recognizefinally--that teaching and writing about language and literature are indeed alienated labor. As with other sectors in the society, control of our work has been wrested from our hands by industrial capitalism, the purpose of our teaching and writing twisted, and therefore made meaningless; consequently, our spiritual lives are given expression during the hours of leisure. We are beings divided between the everyday and the esthetic, between work and play. Indeed, our very roles as critics, teachers, and writers derive from the industrial revolution having made work unbearable, and thereby creating a mass market for leisure, for those literary productions which console us during the hours of escape from work.

There is no escape from such historical imperatives. We may construct ideologies which appear to release us from the bonds of the social system, but our students, departments, schools, and deans will still be there. As will the often intractable subject matter we try to teach. Intractable, because often enough our courses are no more than required obstacles on the way to certification. But more deeply, because in our classrooms we can hardly hope to bridge the gap between our everyday lives and the leisure time we occasionally fill with literature. If we take our work seriously, we would hope that the works studied by our students might weave themselves into the fabric of their ordinary lives. But our culture has saddled them--and us-with an autonomous esthetic realm. Literature is a diversion, a spectacle. And either our students become voyeurs, feeding on the experience of others, or they are bored, unmoved as stone. I doubt that we can even begin to rectify this condition unless we make our professional activity part of the wider cultural struggle to unite the realm of esthetics with that of practical activity. No small order. Indeed, such a unification seems to imply nothing short of some form of cultural upheaval. Alas, such revolutions in the relationship of art to life, play to work, do not happen magically; they rarely happen in class- rooms or in the pages of scholarly journals. But the choice is either to join the struggle, or to accept the legacy of industrial capitalism--a legacy where neither work nor play gives us the means to survive as whole human beings.

\section{I as well as many other students and teachers--often after periods spent organizing and teaching classes in Freedom Schools in the South, in Free Universities on the home campus, or as part of community projects--rediscovered our subject, and found that the academic isolation of literature was not a law of nature or even a social necessity.}

The struggle to open up the enclave has, of course, been going on all around us. It is part of that history of the 1960 's many are trying to forget. I found the struggles of that decade to be exhilarating, and amongst the few reasons for remaining in the profession. I as well as many other students and teachers--often after periods spent organizing and teaching classes in Freedom Schools in the South, in Free Universities on the home campus, or as part of community projects--rediscovered our subject, and found that the academic isolation of literature was not a law of nature or even a social necessity. My comrades and I had a subject to teach once we liberated it from the dogmas of the profession. This we came to understand as we engaged in the practical activity of trying to change the social arrangements which imposed those dogmas. Such activity forced us to reconsider the objectives of our teaching, to question the profession's dearest assumptions, finally to criticize the cultural uses of language and literature itself. And with such questioning and understanding came the confidence--more, the emotional necessity--to transform our professional practice. The forces of insurgency within our society--those who have been trying to knock down the walls--have pointed the way toward a literary and critical practice which goes beyond professional requirements. The writings of Malcolm X, Eldridge Cleaver, and George Jackson, for example, are an intimate part of the movement for black liberation. Such writings are one component of lives engaged in learning and teaching about liberation; of lives spent in political organizing, going to prison, getting shot; of trying to heighten one's own consciousness and that of one's comrades. No doubt, we can work Jackson's Prison Letters into the standard curriculum; once there we might locate their essence within several literary traditions, and proceed to analyze their rhetorical devices with the most devoted 
care; after such labors we might even adjudge them great works of art, according to the most reputable critical canons. We might. But that's our hang-up. Our activities, though well-intentioned, would miss the point. Within the academic setting we can hardly hope to experience the cultural impact of the Prison Letters on the masses of black people. Malcolm $X$, Eldridge Cleaver, and George Jackson may inspire us to change our literary practice. But their work is not something to be wondered at or fed on in the realm of pure spirit.

There are similar lessons to be learned from the writing and curriculum planning of the women's movement. The objective of female studies is not simply to create one more department or another interdisciplinary grab bag, but to change the consciousness of women. And more. Changing consciousness is seen as part of the struggle to transform male-dominated institutions, and to humanize relationships between the sexes. Consequently, feminist literary criticism has profoundly challenged the notion of literature as a selfenclosed field with a set of autonomous rules. Here the concern of criticism is with what literature does to people's heads; how it serves to fix sexual stereotypes; how it twists the consciousness of women--and how this can be changed. The feminist critique challenges us to change the canon of literature, to radically shift our valuations of that canon, and to remember that in the classroom we are men and women affecting the thoughts and feelings of other men and women. In short, feminists do not regard literary study as an activity apart from the general concerns of feminism.

The literary practices of black revolutionaries and of feminists suggest possibilities for our own transformation. Significantly, both movements had to force themselves rather noisily on the profession. Departments of language and literature were hardly playing a vanguard role during the upheavals of the 1960's; neither are they likely to do so today. Yet there are many things we can do (and many places in which to do them) toward initiating or carrying on the tasks of transforming the profession, the society, ourselves. I have time to pick over but a few bare bones. Tactical flesh will have to be added.

1. The MLA. Perhaps it is too much to expect a real transformation here. The monster has been shaken. But its response to every challenge is to create machinery that will absorb the shock--as is the case with the Delegate Assembly. The Association's Sections and Groups reify the structure of the profession; within these fraternal lodges, paternalism can do its benevolent work of promoting the careers of the deserving young. Nearly everyone treats the reading of hundreds of papers as a cynical farce. Yet publicly most are silent for fear of upsetting the routine, or invading anyone's preserve. Indeed, the groups keep increasing, as more and more subspecialties get carved out of the field. Yet the monster can be moved, as well as shaken: the work of the Commission on Women shows us that. We must keep pushing the Association to make it more responsive to the needs of Third World people and of job seekers; to make it support those of its members who are victims of political repression; and, perhaps most important, to make its meetings, journals, and publications vehicles for those intellectual and social movements which are engaged in the strenuous but life-giving pursuit of transforming consciousness, rather than affirming, year after year, issue after issue, what hardly needs to be affirmed.

2. Our Departments. There is the curriculum. In most places it is being changed. But the changes rarely amount to more than a shifting around of authors and books. The new courses should derive not from a different mode of dividing our field, but from human and social need, from the central concerns of the world we live in. Some years ago, depressed by an awareness that our students could see no alternatives--other than dropping out--to spending their lives serving the corporate economy and the war machine, a colleague in linguistics and I began, after much discussion and picking of friendly brains, to teach a course about the intelligentsia's possible roles in social change. Literature was one component of the course, as were history, social theory, group projects, keeping journals, what not. Our students wanted to discover how the culture channels them into destructive and unsatisfying work, and what they could do about it. Working on this course forced us to break out of our specialties, as it forced us out of our individualistic, competitive, and privatized scholarly habits, since we really had to work with groups of students both in the classroom and in the world outside it. In spite of the emotional wrenchings and the inevitable feelings of intellectual insufficiency, the course renewed our sense of the possibilities of intellect, since on occasion we felt ourselves relating knowledge and inquiry to the lives of our students-and ourselves. Teaching the course was an enormously hopeful experience. It also took up endless amounts of time. Thus if younger people are to have the time to explore such possibilities, the policy of publish or perish must be abolished.

3. The Schools We Work In. We should join students and community people in the struggles to transform the schools. For one thing, few of the plans we might have for departmental reform will work, or even take place, unless we change their setting. Can we democratize a department's governance if the administration will not allow it? Can we add experimental courses if our budget has been cut? Can composition courses be made occasions for learning if class size keeps going up? How are we to reward the teacher who really takes risks if the provost can turn down a department's recommendation for tenure? Underlying these facts of departmental life are the political pressures which force schools to serve those with power, rather than the masses of people. Many find it unnerving to work in such institutions. They can quit. But it might be more useful, even interesting, to challenge the powers, and to redirect the purposes served by our schools.

\section{RADICALTEACHER}


4. The Society. The schools cannot be transformed unless we change the priorities of the society they serve. Given the imperatives of industrial capitalism, this means changing the social system. We can hardly make our departments less competitive, if competitiveness is a necessary survival skill in the larger society. Those who would transform the institutions in which they work must seize control of them. And this can only happen within the context of a wider movement for radical social change. We should become part of such a movement.

Now, you are no doubt aware that involvement in the activities I have suggested puts you in danger of becoming or remaining jobless. Therefore, unionization is a necessity. Many academics choke on that particular horse pill: it comes much too close to unveiling the nature of our activities, and undercutting most humanist pretenses. We sell our labor. We are workers under industrial capitalism. If we understand that, we can understand our alienation, our sense of powerlessness. For teaching we collect wages: that is our basic connection to educational institutions, not the claims of humanist rhetoric. We are, in short, an intellectual proletariat. Consciousness of this condition can lead to selfhatred or cynical careerism. It can also lead to our uniting around the oppression we share with other alienated workers, the better to rid ourselves of the oppressors.

Are any of these changes likely to occur? Or are my suggestions no more than utopian rhapsodies? I have no desire to invite people to place their necks in a noose; nor do I much admire tragic heroes and heroines fighting for an inevitably lost cause. The study of literature has not turned my brain that much. Where the profession and the larger society are heading is not obvious. There have been revolutionary changes in large parts of the world during the past thirty years. As the United States tries to hold on to its empire, it is being shaken by great historical forces. These have, of course, had their effect on the profession, as they have affected our whole culture. The changes in the profession have rarely come from within, but, on the one hand, from the pressure of those who rule, or, on the other, from the masses of people who want their share of our intellectual riches. But the changes have, in fact, occurred. History has provided us with levers. One such is the proletarianization of intellectual workers. The resulting disjunction between what we claim to do and the actualities of teaching, writing for $P M L A$, and coming to conventions like this one makes those actualities nearly unbearable. The problem facing us, I want to stress once more, is where we are to turn after attaining such knowledge. Consciousness about the falsity of one's work and life may lead a member of the intelligentsia to ally himself or herself with the revolutionary forces trying to transform social relations. It may also lead to shoring up one's professional enclave with ever stronger ideological mystifications, or, if necessary, firing the troublesome, or, finally, calling in the police or the troops. If we and the bulk of our colleagues decide to go by this route, we shall not only lock ourselves in a prison, but destroy ourselves, for the profession, as the spectacle of our unemployed students and colleagues vividly shows, has begun to outlive its usefulness to the industrial state.
Let me put speculations about the future aside. History has presented us with options; it has aligned the forces. I have told you that many of us had our sense of purpose-our vocation--renewed by the struggles of the 1960's; we began to feel that our work flowed into and was impelled by the turbulent currents of world history. Those currents flow on; the struggles of the 1960's will continue even if we close our eyes. There are no ways of remaining neutral inside institutions that are partisan. It is up to us to choose which side we are on.

(Note: The Presidential address delivered at the 86th Annual Convention of the MLA, in Chicago, 27 December 1971.)

\section{Postscript}

\section{by Richard Ohmann}

In his MLA address, Louis developed several lines of argument that ran against the standard ideology of literary studies, and represented positions thrashed out in the Radical Caucus and New University Conference. In particular, he challenged the cherished idea that disinterested literature humanizes its devotees and their societies, proposing instead that it does its work only through institutions, and therefore is not disinterested, but always political. He works out this idea in the dignified register of MLA discourse, and in this way distinguishes it from the sometimes-rude critique carried on within the student movement at the time. His other departure from the conventions of MLA presidential rhetoric is to focus on labor, especially the labor of entrants to our profession looking for unalienating labor and finding something very different. This was a startling topic for a presidential address. Possibly those in attendance were chiefly antiwar and otherwise radically involved enough to take Louis as a political guide. If so, what did they hear him advocating, and how did it turn out?

His call for attention to non-canonical texts and voices won the day. It had already gained traction from civil rights and black power activists and from second wave feminism. These movements, especially feminism, established themselves as reputable and influential in the MLA. The literary curriculum changed. MLA programs broke open the canon. Furthermore, Louis' position that writing and reading are charged with political interests became solidly established. His proposals gained wide currency. The profession changed.

What about the four institutional upheavals he called for?

- The MLA: as he said, it was "too much to expect a real transformation here." True, it became more responsive to the needs of women, third world people, and job seekers. But to redirect its energies toward advocacy, struggle, union-like activism was indeed "too much." And the MLA, while still one of the larger professional organizations, is a far smaller part of the academic landscape now than in 1971. Its membership has fallen $25 \%$, while the number of people teaching in 
colleges and universities has more than doubled. Louis worked hard to make the organization more progressive. So did the Radical Caucus. Success was uneven and unstable.

- Our Departments, our professional "locals": The progressive work of curriculum and culture Louis wanted for them required an end to "the policy of publish or perish." That did not happen. Instead, departments became channels for the rule of the central administration.

- The Schools We Work In: Louis spoke of political pressures that "force" universities to serve those with power rather than masses of people. The Republican takeover of the last 40 years has made that neoliberal goal national policy.

- The Society: the transformation of our local institutions "can only happen within the context of a wider movement for social change. We should become part of such a movement." Could this, finally, be the time for revolution? "Not in my lifetime," Louis said when I put that question to him 50 years or so ago. He was right. 